\title{
Tecendo Redes pela Igualdade: Meninas Adolescentes de Comunidades de Baixa-Renda Debatendo sobre as Relações de Gênero e a Violência Contra as Mulheres
}

\author{
Weaving Webs for Equality: Adolescent Girls from Low-Income \\ Communities Debating Gender Relations and Violence against Women
}

\author{
Telma Silva Low \\ Universidad de Valencia \\ telmalow@yahoo.com.br \\ Danielly Spósito Pessoa de Melo \\ Universidad de Valencia \\ daniellysposito@hotmail.com
}

\section{Resumo}

A construção do conhecimento nos permite (des) aprender e (re) significar valores, ideais e práticas de vida, especialmente quando é feita a partir do encontro e diálogo entre academia e comunidade. A igualdade de oportunidades entre homens e mulheres também parece possível quando tem nos fundamentados nessa premissa. Este artigo visa, portanto, refletir sobre os discursos construídos por meninas adolescentes, moradoras de duas comunidades de baixa-renda de Recife, com respeito ao tema de gênero e violência contra as mulheres.

Palavras - Chave: Adolescência; comunidade; gênero; violência; subjetividade

\begin{abstract}
The construction of knowledge allows us to (un) learn and (re) define values, ideals and practices of life, especially when it is made from the encounter and dialogue between academia and community. Equal opportunities between men and women also seem possible when we base ourselves on that premise. This article aims to reflect on the speeches made by two teenage girls living in low-income communities in Recife, with respect to gender issues and violence against women.
\end{abstract}

Keywords: Adolescence; community; gender; violence; subjectivity 
Tecendo Redes pela Igualdade: Meninas Adolescentes de Comunidades de Baixa-Renda Debatendo sobre as Relações de Gênero e a Violência contra as Mulheres.

\section{Contextualizando Nossas Práticas}

Ao longo de nossa atuação acadêmica e profissional temos lançado-nos a investigar e intervir no âmbito das relações sociais e humanas, especialmente nos contextos das comunidades de baixa-renda e das políticas públicas voltadas para crianças, adolescentes e mulheres.

É assim que temos percebido que a pesquisa e o trabalho realizado junto às pessoas - e (em) suas relações - demanda que consideremos, diante de toda amplitude, singularidade e complexidade, que ao longo do tempo a categoria sexo vem marcando o modo como essas são, sentem, pensam, interagem, atuam etc. na sociedade (FOUCAULT, 2009; BOURDIEU, 2000). .

Não é à toa, portanto, que antes mesmo do nascimento, a cultura parece (re) criar um processo de significação, representação e imaginação diante desse novo ser, que tende a gerar muitas 'especulações' em torno da identificação e definição do seu sexo biológico $^{2}$. É daí que surge a tão famosa pergunta: é menino ou menina?

A resposta a esta indagação e a constatação de que esta nova criatura traz consigo um pênis ou uma vagina surge como um fator importante. Isso se dá porque, na cultura ocidental, a identificação do sexo anatômico 'oferece' ao bebê um 'enquadramento' que posteriormente pode(rá) funcionar como identificação - dentro daquilo que a sociedade atribui como 'legítimo' às formas de ser homem e mulher no mundo.

Sem dúvida, diante disso, podemos compreender melhor a então célebre frase de Simone de Beauvoir: 'ninguém nasce mulher, torna-se mulher'. Que, para nós, funciona como um alerta frente ao processo de construção social não somente do 'ser mulher', mas também do 'ser homem'.

Com os/as adolescentes não tem sido diferente. Observamos que a construção social da adolescência 'sugere' que meninas e meninos devem se desenvolver e se inter-relacionar a partir de características que aparecem como 'próprias' as suas (inter) subjetividades e fases do desenvolvimento e que, por conseguinte, também estão atravessadas pelo sistema sexo/gênero ${ }^{3}$.

De modo que tende a existir - e persistir - na adolescência uma busca e esforço de responder e perpetuar os padrões femininos e masculinos vigorantes, mesmo diante da postura transgressora e questionadora que muitos/as adolescentes tendem a apresentar e representar (BENLLOCH, 2008; TUBERT, 2008; BONILLA).

O que ademais está claro é que, acoplado aos padrões do sistema sexo/gênero, existem outros modelos 'vendidos' pela sociedade, especialmente através da mídia, que reforçam e refletem os protótipos de consumo e de 'objetificação' que fundamentam muitas das relações na atualidade (ESCOSTEGUY e JACKS, 2003).

A grande questão que pontuamos é que este processo de construção das relações tende a favorecer a emergência de um leque de desigualdades que se referem fundamentalmente ao exercício de poder (assimétrico) entre homens e mulheres, que muitas vezes culmina na violência de gênero.

Dentro deste contexto, o que nos preocupa é que esses fenômenos geralmente acontecem - e se (re) produzem - sem que os indivíduos e a sociedade questionem e reflitam criticamente a respeito de suas relações intra e interpessoais. $\mathrm{O}$ mesmo acontecendo com os/as adolescentes.

Neste artigo, visamos, portanto, refletir sobre o papel da adolescência no processo de (des) construção dos valores e práticas sexistas, como também no que se refere à violência de gênero.

\section{Adolescentes como Protagonistas na Construção do Conhecimento}

Desde o processo de nossa formação que 'despertamos' nossos olhares para a construção de uma ciência também voltada para a prática. Não no que se refere a uma aplicabilidade estrita do conhecimento à realidade, como se a teoria fosse ' $\mathrm{A}$ ' verdade e, portanto, tivesse o poder de ditar e dizer sobre o funcionamento do cotidiano. Se não que buscando uma maior aproximação e inter- relação entre: realidade, demandas da sociedade e produções/trabalhos da academia. A fim de 'romper' os muros invisíveis que ainda separam e apresentam sociedade e universidade como dois mundos distintos, apartados e não conectáveis.

$\mathrm{Na}$ verdade, o percurso acadêmico-profissional que vamos trilhando não converge com os padrões de uma ciência positivista, mas sim com uma noção de que existe uma diversidade de saberes, onde o conhecimento científico é apenas mais um entre tantos.

Isso significa dizer que acreditamos numa teoria que se faz com e na relação com a prática. Que responde, reflete e dialoga com as demandas da população, especialmente das pessoas que se encontram em situação de vulnerabilidade.

De modo a questionar a objetividade e refutabilidade dos fatos, a neutralidade científica e a mera noção/relação do/a pesquisador/a - como 
Tecendo Redes pela Igualdade: Meninas Adolescentes de Comunidades de Baixa-Renda Debatendo sobre as Relações de Gênero e a Violência contra as Mulheres.

aquele/a que tem o domínio e é o/a dono/a do saber versus o/a pesquisado/a - aquele/a que responde às demandas do/a primeiro/a.

Essa ciência nos remete, pois, à ideia do conhecimento como algo dinâmico, em constante processo de transformação, reflexão e (re) (des) construção de significados, verdades e sentidos (ROLNIK, 1995). Logo, a relação que estabelecemos entre teoria e prática se faz cada vez mais 'viva' em nossa formação e atuação. Porque nos possibilita questionamentos, (re) visões, inquietações e indagações que somente os livros não nos permitiram ter; ao mesmo tempo em que nos oferece olhares e compreensões que apenas a prática não nos ofereceria (SPÓSITO, 2009).

Sem embargo, foi pensando um pouco nesse diálogo entre teoria e prática que decidimos realizar esta investigação qualitativa, a qual contou com a participação e o protagonismo de 14 (quatorze) meninas adolescentes, com idades entre 13 e 16 anos, moradoras de duas comunidades de baixa-renda de Recife-Pernambuco/Brasil: Brasília Teimosa e Santa Luzia $^{4}$.

A diferença principal entre um grupo e outro era que as seis (06) adolescentes de Brasília Teimosa nunca haviam tido acesso a atividades de sensibilização, formação e capacitação em temas relacionados ao desenvolvimento sócio-pessoal da adolescência, como por exemplo: gênero, saúde e sexualidade, cidadania, violência, drogas, entre outros.

Enquanto que as oito (08) adolescentes da comunidade de Santa Luzia estavam participando de um trabalho de formação, que vinha sendo realizado há mais de um ano, e que as preparava - juntamente com outros meninos e meninas - para serem Adolescentes Multiplicadores/as de Informação (AMIN) dentro das suas comunidades. Esta era uma capacitação realizada pela ONG Grupo AdoleScER.

A pesquisa de campo tinha o objetivo, portanto, de investigar como essas adolescentes abordavam os temas da adolescência, relações de gênero e violência contra as mulheres a fim de identificar se havia diferenças significativas entre os discursos do Grupo I e do Grupo II.

Nossa hipótese era de que as adolescentes do Grupo II teriam um discurso mais crítico e bem elaborado (em relação às meninas do Grupo I), já que participavam de um grupo de formação e sensibilização sobre os temas citados. A fim de comprová-la ou não fomos para a prática.

A pesquisa foi desenvolvida em três (03) etapas consecutivas. $\mathrm{Na}$ primeira, realizamos algumas reuniões de articulação, reflexão e discussão para definir o perfil dos grupos, os dias dos encontros, a assinatura do termo de consentimento por parte dos/as familiares e/ou responsáveis pelas adolescentes, etc. ${ }^{5}$

$\mathrm{Na}$ segunda, aconteceram os encontros dos grupos de discussão, dois em cada comunidade, com aproximadamente duas horas de duração cada. Nesses utilizamos a técnica de grupos de discussão, que é uma técnica espanhola muito utilizada nas investigações sociais qualitativas e muito semelhantes aos grupos focais. Entendida como:

Una técnica de investigación social que [...] trabaja con el habla. En ella, lo que se dice -lo que alguien dice en determinadas condiciones de enunciación-, se asume como punto crítico en el que lo social se reproduce y cambia, como el objeto, en suma de las ciencias sociales. En toda habla se articula el orden social y la subjetividad (DELGADO e GUTIÉRREZ, 2007, p. 289).

Em outras palavras, podemos dizer que esta é uma técnica que valoriza e (re) conhece o protagonismo dos sujeitos pesquisados, destacando a importância dos seus discursos individuais e também considerando as possibilidades de confrontação, transformação e (re) produção que esses mesmos discursos podem assumir quando estão diante dos demais. De modo que as falas dos sujeitos refletem o 'lugar' de articulação tanto dos modelos e normativas sociais vigentes, como das formas de subjetivação existentes.

No processo de desenvolvimento e facilitação dos grupos $^{6}$, nos dávamos conta de que nossa atuação e presença como pesquisadoras/facilitadoras também pareciam repercutir no processo de (re) produção dos discursos e saberes construídos por e entre as adolescentes. Principalmente porque trabalhamos desde o ponto de vista de que pesquisadoras e sujeitos participantes/protagonistas da pesquisa se afetam mutuamente a partir dos (des) encontros intersubjetivos que acontecem nos grupos:

$\mathrm{O}$ pesquisador, além de ser um sujeito participante, (...) converte-se em sujeito intelectual ativo durante o curso da pesquisa (...) e o sujeito pesquisado não é simplesmente um reservatório de respostas (...) o sujeito na realidade, não responde linearmente às perguntas (...) mas realiza verdadeiras construções implicadas nos diálogos nos quais se expressa (GONZÁLES REY, 2002, p. 55-57).

A terceira e última fase da pesquisa, correspondeu ao processo de análise das informações e apresentação 
Tecendo Redes pela Igualdade: Meninas Adolescentes de Comunidades de Baixa-Renda Debatendo sobre as Relações de Gênero e a Violência contra as Mulheres.

dos resultados. Para tanto, utilizamos a técnica de análise de conteúdo que nos ajudou a compreender, a partir de cinco (05) categorias definidas, como as adolescentes dos Grupos I e II abordaram os temas citados.

Ao final, os resultados comprovaram nossa hipótese, revelando a existência de diferenças significativas entre os discursos das meninas moradoras da comunidade de Brasília Teimosa e às da comunidade de Santa Luzia. Especialmente no que se refere a uma compreensão mais crítica e elaborada com respeito à construção social do ser homem e do ser mulher. Bem como da violência contra as mulheres que, segundo o Grupo II, é consequência dos valores, relações e comportamentos machistas, os quais não são suficientes para justificá-la.

Diante disso, vimos como o sistema sexo/gênero atua - mesmo sem que nos demos conta - nos (des) (re) construindo como sujeitos sexuados (mulheres e homens), ao mesmo tempo sendo (des) (re) construído por nós, a ponto de repercutir nas nossas (inter) subjetividades, (inter) relações e práticas de vida.

\section{Questionando a Realidade: Diálogo entre Teoria Prática}

Refletimos, portanto, sobre o que de fato podemos considerar como 'natural', puramente biológico e 'normal' em nossa sociedade? Por que usamos tantas nomenclaturas, definições, compreensões, interrogativas, categorias etc.? Será que elas de fato nos ajudam a compreender o mundo e (em) seus fenômenos? Essas categorias e denominações são uma invenção social que marcam - e ao mesmo tempo são marcadas - por um determinado tempo e contexto histórico político e cultural? Por que será que elas não favorecem a existência da igualdade entre todos/as, valorizando e respeitando às múltiplas diversidades?

Esses e outros questionamentos vêm possibilitando à sociedade uma (re) visitação das ordens vigorantes em prol da transformação da realidade. A grande maioria deles, inclusive, se destina a revisar, examinar e visibilizar os 'principais' processos históricopolítico-culturais da humanidade, a partir das vozes, mobilizações, ecos e reflexões trazidas pelas teorias e movimentos feministas e de mulheres, especialmente nas últimas décadas ${ }^{7}$.

Dialogaremos, a partir da fala das adolescentes, com alguns aspectos teóricos que consideramos importantes. Iniciamos com o caso da significativa repercussão que os estudos feministas promoveram na vida de homens e mulheres ao realizar uma (re) leitura dos processos históricos da humanidade. Constatando que, durante muito tempo, uma única história nos foi contada e legitimada socialmente: uma história feita 'por, entre e para homens'.

De modo que os livros, as novelas, os filmes, a literatura, entre outros, mostravam geralmente os homens como os únicos e principais protagonistas dos fatos, acontecimentos, descobertas e produções mais relevantes da humanidade. Enquanto que as mulheres surgiam como coadjuvantes e/ou nos papéis de esposas, amantes, criadas, etc.

Tudo isso favoreceu a criação de um imaginário social, que pensa as mulheres como não participantes dos grandes eventos da história, reforçando a noção de que elas não tinham 'perfil, habilidades e natureza' para atuarem como tal, isto é, para serem protagonistas da realidade (BOSCH; FERRER e ALZAMORA, 2006).

Assim, durante séculos, (re) transmitimos de geração em geração, que era reservado e 'próprio' da 'natureza' das mulheres tudo aquilo que se referia ao âmbito da reprodução e do espaço doméstico, como as atividades de cuidado, de limpeza, a maternidade, entre outros. Todas essas consideradas tarefas pouco valorizadas socioeconomicamente ${ }^{8}$, que passam invisíveis no processo produtivo.

Mas, na verdade, esse cenário muda quando lemos essa mesma história com base na perspectiva feminista. Pois, aí compreendemos que inúmeras mulheres foram atuantes e protagonistas em todos os tempos, inclusive rompendo e questionando os padrões e modelos patriarcais 'supremos', que a todo tempo tentavam colocá-las no lugar de subordinadas. Enfim, muitas mulheres não estavam alheias nem satisfeitas com o destino 'final' e 'natural' que a sociedade as oferecia pelo simples fato de 'ser' mulher.

Não é à toa, portanto, que a sociedade patriarcal insistia na criação de mecanismos que legitimavam e naturalizavam a dominação masculina como meio de submeter e controlar as mulheres (BOURDIEU, 2000). De modo que:

[...] se han ido promulgando leyes con la intención de "legalizar" esta sumisión femenina y asegurar el control de la vida de las mujeres, cuyo derechos serán inexistentes durante larguísimos períodos de la humanidad [...] se les enseñará a someterse a la autoridad masculina (BOSCH; FERRER e ALZAMORA, 2006, p. 29).

O que vemos é que mesmo diante de todos esses obstáculos e desafios, que apontam para a existência de uma sociedade desigual e machista, como mostram 
Tecendo Redes pela Igualdade: Meninas Adolescentes de Comunidades de Baixa-Renda Debatendo sobre as Relações de Gênero e a Violência contra as Mulheres.

as teóricas, muitas mulheres seguiram (e seguem) se (re) organizando e lutando contra o caráter hegemônico e opressor do sistema sexo/gênero.

Entendemos, deste modo, porque o direito ao sufrágio, ao acesso às universidades, à atuação no mundo público político, ao debate sobre a remuneração e valorização das atividades do âmbito doméstico, entre outros são celebrados, (re) lembrados e considerados símbolos das lutas, conquistas e desafios feministas. Vemos, portanto, que uma nova história é possível de ser contada implicando:

[...] necesariamente la redefinición y ampliación de nociones tradicionales del significado histórico, de modo que abarque la experiencia personal y subjetiva los mismo que las actividades públicas $\mathrm{y}$ políticas (SCOTT, 1990, p. 25).

Destacamos, então, que este novo e amplo olhar histórico, que parece ser mais crítico, questionador e revelador da realidade e vida dos indivíduos e/em suas relações, ao incluir, considerar e visibilizar também o protagonismo das mulheres, aponta para o início de um processo de transformação social que dialoga e responde à perspectiva de igualdade entre os sexos/gênero.

Nos grupos que realizamos, as adolescentes tendem a ressaltar e reconhecer as conquistas das mulheres, principalmente quando duas delas afirmam que:

Eu acho que machismo é um preconceito (...) Antes a mulher não podia usar short, calça porque era coisa de homem. Já não podia trabalhar porque era coisa de homem, não podia votar. E hoje as mulheres já conseguem tudo isso. Eu acho que as mulheres já quebraram um pouquinho do machismo do homem (A2, Comunidade de Santa Luzia - Grupo II).

Tudo que os meninos podem fazer porque a gente não pode? (...) eles são médicos a gente também pode ser médica, eles podem fazer psicologia, a gente também pode. Então eu acho que não tem empecilho, não tem assim possibilidade da gente ser diferente deles (...) (Pl, Comunidade de Brasília Teimosa - Grupo I).

Vemos, portanto, que as adolescentes protagonistas dos dois grupos sinalizam e convergem quanto à ideia de que a igualdade entre homens e mulheres é uma possibilidade real. No entanto, o Grupo II consegue fazer uma breve leitura histórica reconhecendo que a igualdade nem sempre existiu e que as mulheres vêm conquistando seus espaços e lugares dentro de uma sociedade basicamente machista.

Assim, percebemos que a reflexão e o debate sobre a temática de gênero possibilitam que as adolescentes exercitem e exerçam uma postura mais crítica frente à realidade social, fragilizando e desconstruindo a hegemonia do sistema patriarcal (LOW, 2009).

Isso se dá, por um lado, quando elas interrogam os motivos que levam nossa sociedade a justificar as diferenças entre os sexos e por outro quando (re) conhecem que ainda vivemos numa sociedade machista $^{9}$. O que não as impossibilita de identificar e nomear alguns avanços e mudanças que marcam as conquistas feministas.

Ressaltamos, portanto, que esse processo de construção de valores, ideias, relações e padrões machistas $^{10}$ se fundamentam na e a partir da significação que a sociedade constrói do aparelho reprodutor e sexo biológico de um indivíduo. É por isso que existem constantes reflexões e debates feministas sobre a não possibilidade de separação entre cultura e biologia.

Visto que uma não existe/nem pode ser (re) significada sem a outra e vice-versa. Isto é, a biologia é feita na e através de determinada cultura, a qual também sofre influência da biologia no seu processo de construir-se e fazer-se.

As adolescentes do Grupo II parecem assinalar um pouco essa não separação, indefinição ou mesmo confusão do que parece ser somente cultural ou apenas biológico/natural aos sexos, mas que na prática não é.

Quando dizem, por exemplo, que:

Também tem esse negócio, que menino brinca de carrinho, menina brinca de boneca. Ai quando menino joga bola $e$ menina brinca de boneca. Aí se a menina vai jogar bola, eles faz de tudo: ai é mulher homem. Isso é estranho menina jogar bola (A7 - Grupo II).

Aí já chama de sapatão (A6 - Grupo II).

Aqui percebemos que as adolescentes interrogam o que acontece com e na nossa sociedade que 'dita' gostos e brinquedos (mandatos culturais) a partir do sexo dos indivíduos (mandato biológico: sexo anatômico).

De forma que a ênfase é dada pela e na relação intrínseca que existe entre as categorias sexo/gênero, que se (des) constroem atribuindo valores, padrões e regras que atravessam a existência dos indivíduos e 
Tecendo Redes pela Igualdade: Meninas Adolescentes de Comunidades de Baixa-Renda Debatendo sobre as Relações de Gênero e a Violência contra as Mulheres.

promovem a construção de relações desiguais entre mulheres e homens (BENLLOCH e BONILLA, 2000).

Assim, uma fêmea tem que ser obrigatoriamente mulher e, ademais, se identificar e compartilhar com um universo feminino ${ }^{11}$, que diz que ela não pode/não deve/não sabe/ não nasceu para gostar de jogar futebol. Caso contrário, ela é classificada de 'sapatão', expressão vulgar que marca, por um lado, que ela desenvolveu uma habilidade considerada socialmente masculina e, por outro, que a enquadra - de modo bastante homofóbico - na categoria de lésbica ${ }^{12}$.

Não é à toa, portanto, que meninos e meninas já têm meio que 'traçado' pela sociedade que eles deverão gostar mais do azul - que simboliza o céu, o mar, o infinito. Ou seja, elementos que pressupõem uma maior liberdade, característica 'embutida' na construção social do ser homem. Enquanto que elas tenderão a se identificar mais com a cor rosa, que revela a fragilidade de uma rosa, um símbolo da natureza que demanda a necessidade de cuidado, de sutileza, etc. (BURIN, 1996).

Ademais eles, tenderão a brincar com carrinhos, jogar bola, brincar de bang-bang etc. Sendo estimulados a exercitar, desde pequenos, a agressividade, o potencial de força, escondendo, disfarçando e/ou mesmo negando seus sentimentos, afetividades, entre outros.

Entendemos aqui porque, quando nos voltamos para a fase adulta, percebemos que 'esse jeito de menino' parece corresponder aos atributos que a sociedade cria como importantes para a atuação no mundo público político, tão habitado e dominado pelo masculino durante tanto tempo (CORSI, 1995; KAUFMAN, 1994).

Enquanto isso as meninas 'naturalmente' são 'premiadas' com os brinquedos de casinha, de cozinha, com uma boneca e seu carrinho de bebê, que se somam as brincadeiras de roda, de costura, de professora, entre outras.

Essa lógica tende a 'prepará-las para as tarefas de cuidado da casa e do/a outro/a, isto é, para o mundo dos afetos e da submissão. Criando e reforçando o imaginário de elas não 'nasceram' para expressar agressividade, para as atividades que demandam força física, para uma atuação pública política de fato, etc.

Quando debatemos com as adolescentes sobre o tema da naturalização das diferenças entre meninas/mulheres e meninos/homens, observamos diferenças significativas entre os discursos dos dois grupos. Construímos, portanto, a tabela abaixo para que visualizemos melhor um resumo dos debates produzidos nos dois grupos.

Percebemos, portanto, que as participantes da Comunidade de Brasília Teimosa ${ }^{13}$, tinham seus discursos mais 'fincados' nos modelos do sistema sexo/gênero em relação às adolescentes da Comunidade de Santa Luzia.

Essas últimas, inclusive, compreendiam - ao mesmo tempo em que questionavam - que existe uma ordem social vigente que intencionalmente (re) produz a desigualdade entre os sexos, desde a infância, a partir da atribuição de papéis e funções sociais diferentes para meninas e meninos que repercutirá no que eles e elas vão ser na vida adulta. Relacionamos, portanto, os discursos do Grupo II às ideias de Bourdieu (2000, p. 117) que diz que:

Los hombres siguen dominando el espacio público y el campo del poder (especialmente, el económico, sobre la producción) mientras que las mujeres permanecen entregadas (de manera predominante) al espacio privado (doméstico, espacio de la reproducción).

Ou seja, toda essa segregação, cultivada e transmitida no processo de socialização das crianças e adolescentes, funciona, sem dúvida, como uma garantia de manutenção e perpetuação da ordem patriarcal vigente.

É assim que todo um 'universo feminino' e 'masculino' vem sendo construído e dividido, seguindo uma lógica binária que se fundamenta - e é fundamentada - numa relação de oposição, complementaridade e hierarquia, expressas também nos estereótipos e papéis sociais, como vimos nos discursos das adolescentes do Grupo I. Parece, então, que essa segregação do mundo em somente duas partes, como afirma Joan Scott, é fruto da:

(...) naturaleza construida históricamente de la oposición (entre varón y mujer) produce sus efectos precisamente ese aire de oposición invariable y monótona: hombres y mujeres (1990, p. 40).

Uma das questões fundamentais e que muito nos preocupa está no fato de que o sistema sexo/gênero não somente trata de fixar e predeterminar essas formas universais, cristalizadas e antagônicas de ser homem e ser mulher. Se não que também naturaliza o domínio deles sobre elas, favorecendo a manifestação de relações permeadas pela violência de gênero.

Ao falarmos de violência de gênero, estamos nos referindo predominantemente a uma construção social que legitima e autoriza que o homem exerça poder ${ }^{14}$ sobre as mulheres, pelo simples fato delas serem mulheres (BOSCH; FERRER e ALZAMORA, 2006). 


\section{GRUPO I}

\section{Ser Homem}

Ser Mulher

\section{Diferenças entre os sexos:}

Quadro 1 - Apresentação das falas das adolescentes diferente (P6).

\section{GRUPO II}

- Os homens deixa tudo sujo, é mais preguiçoso. Os homens só faz trabalhar e dá dinheiro pra mulher (...) (P3)

- O homem é mais brigão do que a mulher (P4).

- É tomar conta do filho, arrumar a casa e comprar... (P2).

- Força, mulher é muito forte. (...) além de esperar a necessidade que ele está passando, ela ainda supera a dificuldade que ela passa diariamente (...) porque ela bota a cabeça no lugar, cuida dos filhos, da casa, do trabalho. A mulher é muito forte, batalhadora, organizada (P1).
- É assim, a palavra homem é o quê? É mais forte pra algumas mulheres, aí os homens pensa que acha que porque é homem tem que mandar na mulher. Aí eu acho que ele deveria ter consciência (...) O homem ele é meio forte, mas só que essa palavra homem ela deveria ser mais fraca (A1).

- A menina às vezes sofre mais preconceito do que o menino. Assim, com um namorado, o que tiver de acontecer, por exemplo, um traiu o outro. Aí pronto, o homem, a maioria as pessoas diz assim, não é o pegador, esse negócio. Se for a menina que trair, aí todo mundo ia falar porque era a menina e outras coisas mais (A3).

- Assim, a palavra mulher pra mim significa: a mulher ela não é um objeto (A1).

- Caderno, a mulher pode usar Barbie, o homem só usa homem aranha (...) Menino com capa de Barbie só se for (...) (risos) (P4).

- (...) o que eu acho que é só de homem e só de mulher eu acho que é mais no pessoal (...) A maneira de se expressar, o jeito feminino, o modo de pensar é
- São coisas que são feitas para meninos e coisas que são feitas para meninas. Quando a mulher dá a sua filha uma boneca, aí ela ta influenciando a sua filha a mexer a boneca pra futuramente ter um filho. E quando dá a um filho, um carrinho, um boneco, bola de gude, uma bola pra jogar ta influenciando ele a ser mais homem, a agir com coisa de homem (A2).

Fonte: Organizadoras do Artigo

Telma Silva Low e Danielly Spósito Pessoa de Melo 
Tecendo Redes pela Igualdade: Meninas Adolescentes de Comunidades de Baixa-Renda Debatendo sobre as Relações de Gênero e a Violência contra as Mulheres.

É assim, portanto, que a representação e o imaginário cultural que associa mulher à fragilidade, inferioridade e submissão vêm sendo combatido pela perspectiva feminista ao longo do tempo. Pois, sem embargo, a violência que sofre muitas mulheres “(...), es inseparable de la noción de género porque se basa y se ejerce en y por la diferencia social y subjetiva entre los sexos" (VELÁZQUEZ, 2004, p. 28) ${ }^{15}$.

Quando fomos analisar os discursos das adolescentes, com respeito a este tema - nos grupos usamos apenas a terminologia violência contra as mulheres em vez de violência de gênero - vimos que os dois grupos compreendem que a violência contra as mulheres envolve não só a agressão física se não que também a violência psicológica e sexual. Este foi um debate que envolveu muitas contradições e (des) construções do que aprendemos e internalizamos a partir do imaginário social.

Mas, de fato, as adolescentes do Grupo I apresentaram um discurso mais 'simplista' que retrata com precisão a representação que a grande maioria das pessoas tem/faz a respeito do tema, especialmente aquelas que não estão sensibilizadas e informadas. Apresentamos, portanto, o que quatro delas disseram a respeito dos 'motivos' que levam as mulheres a sofrerem violência:

Porque elas permitem ser violentada, permitem ser maltratadas porque hoje em dia está tudo mais fácil. A gente se for maltratada pode chegar na delegacia das mulheres e prestar uma queixa (P1, Grupo I).

Não se dá o pudor (P4, Grupo I).

Acaba se desrespeitando, por ela querer mesmo (P2, Grupo I).

Porque umas não se dão o valor e têm que apanhar (P5, Grupo I).

Enquanto que as adolescentes do Grupo II pareciam expressar suas inquietudes, com base na ideia de que este é um tema complexo que remete e se relaciona com tantos outros, como: a) a questão da impunidade - que denúncia a lentidão e fragilidade da Justiça e do Estado tanto no sistema de proteção às vítimas e aos/às seus/suas filhos/as, quanto à punição e responsabilização do agressor; b) a dependência econômica; c) o uso de drogas e álcool; d) a dependência afetiva; e) a questão da crença de que a vivência do amor necessariamente passa e pede a presença do ciúme, quando esse na verdade aponta para a ideia de possuir o/a outro/a e um/a ao/à outro/a, etc.

Elegemos, portanto, três falas que sintetizam, de modo geral, os discursos do Grupo II a respeito da violência:

Nem sempre esse negócio de denunciar faz resolver. Porque tem vezes que a mulher denuncia o marido e no outro dia o marido já tá solto. Não adiantou de nada (Al, Grupo II).

Hoje em dia, os homens tá tudo matando a mulher porque denuncia (A2, Grupo II).

Porque eles pensa que as mulher é um objeto dele. É uma coisa dele e ele pode fazer o que quiser dela. E a outra coisa é isso: "acha que é uma coisa que ele compra e é dele eternamente (A2, Grupo II).

(...) aí eles podem fazer o que quer (...) dominar (...) de querer fazer o que quer, na hora que ele quer. E se ela não fizer, ele dále ou se não mata (...) E às vezes não é nem o homem que mata, às vezes ela mesma pensa: "já cansei de apanhar", aí vai e se suicida (A6, Grupo II).

Diante de todas essas respostas, construídas e produzidas no e pelo Grupo I e Grupo II, mais inquietações, reflexões e questões surgem e surgiram em nós. De modo que muitas vezes chegamos a nos perguntar - e inclusive duvidar - da eficácia desse trabalho e dos resultados e impactos que de fato alcançamos.

\section{Limites e Possibilidades da Práxis Profissional: Fazer da Utopia uma Realidade Possível}

Mas, apesar de sabermos que as mudanças ainda não acompanham as inúmeras demandas pessoais, familiares, comunitárias e sociais vemos na prática o quanto é importante seguir trabalhando. Isto é, seguir semeando, sensibilizando, refletindo, escutando, debatendo e in (for)mando sobre outras possibilidades mais pacíficas, igualitárias, justas, respeitosas e éticas de ser, conviver e relacionar-se a situação estaria ainda mais crítica.

$\mathrm{O}$ que significa dizer que o número de mulheres que sofrem violência e são assassinadas pelos seus (ex) maridos/companheiros estaria ainda mais alto. Pois, de 
Tecendo Redes pela Igualdade: Meninas Adolescentes de Comunidades de Baixa-Renda Debatendo sobre as Relações de Gênero e a Violência contra as Mulheres.

acordo com AZAMBUJA (2004):

Cerca de cinco milhões de mulheres são vítimas de abuso severo por parte de seus companheiros/maridos em todo o mundo sendo que destas, cerca de $50 \%$ a $60 \%$ são estupradas. Em torno de $75 \%$ dos casos de violência intrafamiliar são cometidos contra mulheres e somente $2 \%$ contra homens. O Banco Mundial calcula que as mulheres perdem entre $5 \%$ e $16 \%$ dos anos de vida saudável em consequência da violência doméstica, o que corresponde a um entre cada cinco dias de saúde (citada em STREY, AZAMBUJA e JAEGER, 2004, p. 269).

Esses dados mostram, portanto, quão grande é o trabalho que ainda temos por fazer. Não somente em prol das mulheres, se não que também dos homens, ou melhor, em defesa da vida do humano independentemente do seu sexo ${ }^{16}$.

Destacamos, assim, uma fala de umas das adolescentes do Grupo II que deixa bem claro que a violência não é 'bem vinda', nem desejada por ninguém, como muitos/as tendem a pensar, se não que reflete - e é reflexo de - uma sociedade desigual em todos sua expressões:

Que gostar é um negócio. Assim, gostar é a gente gostar de fazer aquilo, e uma coisa é que ninguém gosta de apanhar. Vocês gostam de apanhar? Ninguém gosta de apanhar, e deixar é ela sabendo que tem direito, que ele não tem direito, mas ela deixa. Não é porque ela gosta não é porque ela sente assim, ele se sente no poder de bater nela e ela se sente como se tivesse dever de apanhar dele (A4, Grupo II).

Antes de finalizarmos, queremos pontuar que as meninas do Grupo II não são melhores, mais inteligentes, mais competentes, mais humanas, etc. que as do Grupo I. Se não que tiveram acesso a um tipo de (in) formação que as possibilitou desenvolver uma visão, pensamento e discurso mais amplo e crítico a respeito do mundo.

De maneira que queremos ressaltar aqui, o mérito que todas e cada uma delas têm em conseguir se desenvolver e viver, dentro de um contexto de vulnerabilidade - que muitas vezes não é só social, mas também familiar e pessoal - que tende a ver/encontrar na violência um meio de sobrevivência, (re) conhecimento, identificação e inclusão. Pois:
A violência não apenas diz "não", mas evidencia demandas sociais de reconhecimento de diferenças, formação de redes de sociabilidade e de "micropoderes", de práticas de "solidariedade fechada", deixando muitas vezes atrás de si, marcas de sangue e lágrimas (DIÓGENES, 2008, p. 89).

Reconheçamos, portanto, o potencial criativo e protagonista que essas e tantas outras meninas e meninos têm e exercem, na busca de (re) encontrar seu lugar no mundo e não seguirem nem caírem no destino que a nossa sociedade já tem meio que traçado para elas e eles.

Pois, muitos/as de nós parece mesmo estar acostumados/as e convencidos/as de que eles/as optam, desejam e trilham os caminhos que os/as levam à exclusão, pobreza, marginalidade e indiferença. Como se a responsabilidade não fosse de todos/as e de cada um/a de nós.

Todavia não pensemos que essas adolescentes estão alheias às marcas sociais que as etiquetamos. Esses elementos perpassaram os discursos produzidos dos dois grupos, tememos como exemplo as seguintes falas:

Eu fico olhando assim minha mãe, eu acho que eu não aguentava não trabalhar, passar o dia (...) Eu me sinto bem tendo as coisas que eu tenho sem precisar trabalhar. Têm muitas meninas aí pedindo, catando lixo, fazendo alguma coisa... E eu me sinto bem, vindo pro adolescer e indo para escola (A7 - Grupo II).

(...) Pra que a gente vai querer ter filhos agora? (A2 - Grupo II).

Pra vir um e matar (...) pra ter um filho e daqui a pouco vem um que quer tirar a vida do filho dela. (A6 - Grupo II).

Eu já passei por isso. Meu pai batia muito na minha mãe, por isso que eu to meio assim. Que eu não gosto muito de falar dessas coisas. Meu pai batia muito nela. E ela era novinha e besta. Exatamente meu pai (...) já quebrou um braço da minha mãe. Minha mãe só vivia com as manchas no pescoço, pelas costas, marcas roxas pelo corpo. Eu já sofri muito por ela (P1 Grupo I). 
Tecendo Redes pela Igualdade: Meninas Adolescentes de Comunidades de Baixa-Renda Debatendo sobre as Relações de Gênero e a Violência contra as Mulheres.

Concluímos esse artigo, portanto, reconhecendo a existência das limitações de nossas atuações, pois sabemos que temos muito a (des) aprender e (des) construir, que o nosso conhecimento ainda é bastante limitado; enfim que nossa prática e formação estão em contínuo processo de transformação, reflexão, (re) visão e (des) fazer-se. Ao mesmo tempo em que identificamos o quão rico e importante tem sido nos mantermos no lugar de aprendizes, sem perder de vista e de foco nossos referenciais teóricos e compromisso ético-político.

De modo que as adolescentes vieram corroborar nosso ideal 'utópico' de que outro mundo é possível. Para tanto, necessitamos (re) criar cada vez mais encontros, espaços e momentos de sensibilização, reflexão, escutas e debates não somente individuais, mas especialmente coletivos.

Assim, estaremos fomentando na sociedade não somente a perspectiva da igualdade entre os sexos, se não que a possibilidade de (re) construção de relações mais saudáveis, empáticas, pacíficas e humanas em todos os níveis e sentidos. Onde o respeito e (re) conhecimento ao/a outro/a e (em) suas diferenças não seja motivo de ameaça, exclusão e negação de sua existência, se não que um exercício de alteridade que favorece a aceitação das singularidades e pluralidade que existem em todos/as e cada um/a de nós (ROLNIK, 1994).

Ademais, as adolescentes também ressaltaram - e de certa forma solicitaram - que engajemos cada vez mais pessoas e instituições que se comprometam e trabalhem eticamente em prol da igualdade entre todas e todos. De maneira que Estado e sociedade civil estejam mais implicados no fomento, elaboração, execução e fiscalização de políticas públicas que promovam a melhoria da qualidade de vida das mulheres e demais pessoas, atendendo de fato as demandas daqueles/as que se encontram em situação de vulnerabilidade.

É possível mudar e (des) construir essa sociedade? O que e como fazer? Como possibilitar que mulheres e homens sejam seres livres e de plenos direitos sobre si mesmos/as e respeito aos/às demais?

Como vemos, quando estamos atuando no social nos damos conta de que as perguntas não param; as respostas parecem não ser suficientes; os resultados e impactos tendem a ser micro dentro das demandas macros existente; a pressa, o tempo e a urgência nos desafiam diariamente.

Enfim, vidas clamam por socorro e nos ajudam a refletir e (re) ver os sentidos e valores que damos a nossa própria existência e a dos/as demais. Bem como as mudanças e ideais que devemos seguir, buscando enquanto indivíduos sociais. Quem tem que começar a mudar, então? Deixemos que as próprias adolescentes respondam e de fato terminem o nosso trabalho, pois as possibilidades de respostas e caminhos também estão e podem ser protagonizados e sinalizados por elas:

Eu acho que a sociedade por completo [...] porque eu acho que é importante o contato, porque só uma pessoa não pode mudar o mundo né?! Tem que ser todo mundo assim pra mudar, uma pessoa só não consegue não (A3 - Grupo II).

Porque o que adianta nossa família mudar e a comunidade continuar naquele pensamento? (A4 - Grupo II).

Nas escolas também, né, fazendo palestras. Acho que o ideal é assim entrar nessa questão de valores (Al - Grupo II).

Nos postos da comunidade, assim com palestras (A6 - Grupo II).

Olhe, quando eu tava aqui no primeiro dia eu me vi assim...que nem um cavalo com um negócio, que tinha minha opinião formada sobre tudo. Ai depois escutando, eu fui me abrindo, escutando um e depois escutando outro, aí eu já fui reformando as minhas opiniões, já fui conhecendo por outro lado [...] Pra gente ver como as opiniões mudam no decorrer do tempo [...] Se a gente tivesse nos anos 70, a gente não ia definir homem [...]como a gente define hoje. Então, a gente ta no século XXI, aí quando a gente tiver no século 30, sei lá, um aí, bem pra frente e a gente fizesse essa reunião, ia ter opiniões diferentes. No futuro se a gente escutar isso, nós já vamos ter opiniões formadas diferentes (P6 - Grupo I).

1 Que coexistem juntamente com outras tantas categorias, como: gênero, raça/etnia, idade/geração, classe social etc.

2 Consideramos que o sexo não é um componente 'puramente' biológico como tendemos a pensar e sim mais um aspecto que é atravessado pela cultura e que junto a essa atua (re) significando o humano em suas relações. É por isso que muitas/os 
Tecendo Redes pela Igualdade: Meninas Adolescentes de Comunidades de Baixa-Renda Debatendo sobre as Relações de Gênero e a Violência contra as Mulheres.

teóricas/os feministas se referem ao sistema sexo/gênero como (re) produtor das desigualdades entre mulheres e homens, destacando inclusive, que a própria biologia é também cultural, de modo que não se pode separá-las, se não em términos de compreensão. Desse modo, ressaltam que sexo e gênero devem ser considerados a partir de suas interrelações (BONILLA, 2000).

3 Aqui nos unimos aos estudos de Franch (2000), Abramovay (2002), Willadino (2003), Diógenes (2008) etc., que questionam o caráter homogêneo e cronológico da adolescência como uma etapa do desenvolvimento humano, caracterizada e entendida pelos estudos clássicos, como uma 'crise normal'.

4 Aqui identificadas como Grupo I e Grupo II, respectivamente.

5 Em Brasília Teimosa contatamos com uma liderança comunitária que conhecíamos, a qual organizou todo o processo de mobilização e articulação das adolescentes e de suas famílias - já que aí não existia um grupo pré-formado como na comunidade de Santa Luzia. O que implica dizer que tivemos que ir às casas das adolescentes do Grupo I, para sensibilizar seus familiares e pedir a autorização dos/as responsáveis para a participação das meninas na pesquisa. Enquanto que a articulação com a comunidade de Santa Luzia, e incluso com os/as responsáveis das adolescentes, se deu através da ONG citada.

6 Todos os grupos foram gravados com a autorização das adolescentes e dos/as seus/suas responsáveis.

7 A palavra feminista tem sido alvo de grandes polêmicas e de uma variedade de interpretação, de modo que para nós ela traz latente todo um conjunto de práticas, ideais e valores éticos e políticos que defende, promove e apresenta a igualdade entre os sexos. Mas, também desafia nossa realidade no sentido de combater e eliminar o sistema patriarcal e capitalista dominante que sustenta a violência de gênero e tantas outras formas de violência. Abrimos esse parêntesis, portanto, para explicar que nem todos os movimentos de mulheres se consideram feministas e que as teorias e movimentos feministas não são feitas somente por, para e entre mulheres, pois também existem homens que são e se definem feministas. Além do fato de que, dentro do próprio movimento e teorias feministas e de mulheres, observamos pontos de divergências, conflitos, aproximações e distanciamentos entre eles.

8 Cada vez mais os movimentos e teorias feministas reivindicam uma nova leitura das atividades consideradas 'femininas' e dos lugares de atuação das mulheres, especialmente no que se refere ao âmbito do doméstico. Pois, está claro que este é um setor da sociedade que propositalmente vem sendo negligenciado e desconsiderado, a partir do ponto de vista econômico, político, social e laboral. Assim cada vez mais as mulheres, que são as grandes trabalhadoras do lar, não têm seus trabalhos legitimados e valorizados e quando os têm lhes são atribuídas baixas e precárias remunerações, que envolve a negligência e não garantia de direitos legais e reconhecimentos socioculturais, como acontece com as empregadas domésticas, por exemplo. (HIRATA, 2008, In: ÁVILA et al, 2008).

9 O tema do machismo também foi debatido no Grupo I, a partir de um discurso menos crítico e mais (re) produtor do imaginário social patriarcal, o que não os tornam menos interessante e/ou importante para o nosso estudo. Ao contrário, pois eram discursos que nos faziam refletir sobre as controversas e força que o sistema sexo/gênero exerce em nossas vidas, tirando de foco o peso da ordem social exerce para destacar os indivíduos, como se fossem seres isolados. Trazemos dois exemplos das falas das adolescentes de Brasília Teimosa: "tem mulher que é muito machista (...), que não querem ver o homem bem, ver o homem feliz..." (P6); "Fica no pé do homem direto e só quer o dinheiro dele pra fazer compras" (P2). Vemos, portanto, que elas transferem a culpa e responsabilidade de um sistema machista operante para o ser mulher - que de fato muitas também são machistas, assim como muitos homens - sem se darem conta de que o machismo é uma construção social que vincula sexo e (a) gênero.

$10 \mathrm{Ou}$ sexistas, androcêntricos, patriarcais, misógino.

11 O mesmo deve ser com os humanos machos que logo são nomeados de homens e que devem se identificar com o mundo masculino.

12 Não vamos entrar nesse debate, mas queremos aqui ressaltar que o sistema sexo/gênero impõe também, além da masculinidade hegemônica, a heteronormatividade. Esta é tida como modelo único, que legitima e naturaliza as relações entre os sexos desde a perspectiva da heterossexualidade. Deixando à 
Tecendo Redes pela Igualdade: Meninas Adolescentes de Comunidades de Baixa-Renda Debatendo sobre as Relações de Gênero e a Violência contra as Mulheres.

margem, portanto, uma diversidade de orientações sexuais existentes e possíveis. Isso significa dizer que a ordem patriarcal cristaliza e determina que a sexualidade humana, que é algo dinâmico, fluido, prazeroso e livre, seja vivenciada e experienciada dentro de um (único) padrão: homem-mulher para fins de reprodução.

13 Àquelas que nunca haviam participado de capacitação e formação em temas relacionados aos direitos humanos, cidadania, saúde e sexualidade, gênero, adolescência etc.

14 Compreendemos poder a partir da concepção de Foucault, que afirma que “(...) o poder não se dá, não se troca nem se retoma, mas se exerce, só existem em ação" (2009:175). Para nós, portanto, o exercício do poder implica uma relação de força circulante e dinâmica que historicamente tem sido exercida de modo desigual nas relações entre homens e mulheres (deles sobre elas), mas também nas relações deles e delas entre si. Pois, a horizontalidade e a igualdade no exercício do poder parece algo ainda muito distante de nossas práticas e relações.

15 Aqui questionamos e combatemos a ideia de culpabilizar tanto a mulher quanto o homem pela questão da violência de gênero. Pois, sabemos que ele e ela fazem parte de um sistema que legitima e constrói as desigualdades de poder como apresentamos ao longo deste artigo. Mas, ao mesmo tempo, vemos defender a necessidade de realizar um trabalho sistemático e contínuo de sensibilização, prevenção e combate à violência, que inclui fundamentalmente a penalização e responsabilização do agressor e o apoio integral à vítima.

16 Sabemos que cada vez mais cresce o número de meninos adolescentes e jovens que morrem envolvidos em brigas, gangues, tráfico etc. Aqui, também, atua os modelos de socialização do sistema sexo/gênero que fomenta o desenvolvimento de um potencial agressivo para homens que pode culminar no desenvolvimento de relações inter e intrapessoais embasadas na violência (KAUFMAN, 1994; CORSI, 1995).

\section{Referências}

ABRAMOVAY, Miriam et al. Gangues, galeras, chegados e rappers - Juventude, violência e cidadania nas cidades da periferia de Brasília. Brasília: UNESCO, Instituto Ayrton Senna, Secretaria de Turismo e Lazer do Distrito Federal e Garamond, 1999.

ÁVILA, Maria Betânia et al. Reflexões feministas sobre informalidade e trabalho doméstico. Recife: SOS CORPO - Instituto Feminista para a Democracia, 2008.

BOSCH, Esperanza; FERRER, Victoria; ALZAMORA, Aina. El laberinto patriarcal: reflexiones teórico-prácticas sobre la violencia contra las mujeres. Barcelona: Anthropos, 2006.

BOURDIEU, Pierre. La dominación masculina. Barcelona: Anagrama, 2000.

BURIN, Mabel. Género y psicoanálisis: subjetividades femeninas vulnerables. Buenos Aires: Paidós, 1996.

CORSI, Jorge. Violencia masculina en la pareja. Buenos Aires: Paidós, 1995.

DELGADO, Juan; GUTIÉRREZ, Juan. Métodos y técnicas cualitativas de investigación en ciencias sociales. Madrid: Editorial Síntesis, 2007.

DIÓGENES, Glória. Cartografias da cultura e da violência: gangues, galeras e o movimento hip hop. São Paulo: Annabume, 2008.

ESCOSTEGUY, Ana Carolina. "Políticas de identidade e os estudos de recepção: relatos de jovens e mulheres". In: CONGRESSO BRASILEIRO DE CIÊNCIAS DA COMUNICAÇÃO, 2003, Minas Gerais. Anais... Minas Gerais, 2003 p. 422- 429.

FOUCAULT, Michael. História da Sexualidade 1: a vontade de saber. São Paulo: Edições Graal, 2009.

Graal, 2009.

Microfísica do Poder. São Paulo: Edições

FRANCH, Mônica. Tardes ao léu: um ensaio etnográfico sobre o tempo livre entre jovens de periferia. 2000. (Mestrado em Antropologia) Universidade Federal de Pernambuco, Recife.

KAUFMAN, Michael. Men, Feminism, and mens's contradictory experiences of power. In: BROD, Harry e KAUFMAN, Michael. (Org.) Theorizing Masculinities. Thousand Oaks: Sage Publications, 
Tecendo Redes pela Igualdade: Meninas Adolescentes de Comunidades de Baixa-Renda Debatendo sobre as Relações de Gênero e a Violência contra as Mulheres.

1994, p. 142-165.

LOW, Telma. Intersubjetividades en la adolescencia: sistema de género y violencia. 2009. Dissertação (Mestrado em Gênero e Políticas de Igualdade) - Universitat de València, Valencia.

MARTÍNEZ BENLLOCH, Isabel (coord.). Imaginario cultural, construcción de identidades de género y violencia: formación para la igualdad en la adolescencia. Madrid: Instituto de la Mujer, 2008.

MARTÍNEZ BENLLOCH, Isabel; BONILLA, Amparo. Sistema sexo/género, identidades y construcción de la subjetividad. Valencia: Universitat de València, 2000.

REY GONZÁlES, Luis Fernando. Pesquisa qualitativa em psicologia: caminhos e desafios. São Paulo: Thomson Learning, 2002.

ROLNIK, Suely. Cidadania e alteridade: o psicólogo, o homem da ética e a reinvenção da democracia. In: SPINK, Mary Jane Paris. (Org.). A cidadania em construção: uma reflexão interdisciplinar. São Paulo: Cortez, 1994, p. 157-176. $\overline{49-61}, 1995$.

Subjetividade e história. Revista Rua, n.1, p

SCOTT, Joan W. El género una categoría útil para el análisis. In: AMELANG, James; NASH, Marie Josephine. Historia y género: las mujeres en la Europa moderna y contemporánea. Valencia: Alfons el Magnánim, 1990. p. 22-56.

SPÓSITO, Danielly. La Violencia de Género en la Comunidad Valenciana: modelo de evaluación participativa de una Política Pública. 2009. Dissertação (Mestrado em Gênero e Políticas de Igualdade) - Universitat de València, Valencia.

STREY, Marlene; AZAMBUJA, Mariana; JAEGER, Fernanda. (Org.). Violência, gênero e políticas públicas. Porto Alegre: Edipucrs, 2004.

VELÁZQUES, Susana. Violencias cotidianas, violencias de género: escuchar, comprender, ayudar. Buenos Aires: Paidós, 2004.

WILladinO, Raquel. Proceso de exclusión e inclusión social de jóvenes en el contexto urbano brasileño: un análisis de trayectoria de violencia y estrategias de resistencias. 2003. Tese (Doctorado en Psicología Social) - Universidad Complutense de Madrid, Madrid.
Recebido em 18 de março de 2011. Aceito em 27 de abril de 2011. 